\title{
Revealing the Potency of Cinnamon as an Anti-Cancer and Chemopreventive Agent
}

\author{
Yonika Arum Larasati and Edy Meiyanto* \\ Cancer Chemoprevention Research Center, Faculty of Pharmacy, \\ Universitas Gadjah Mada, Yogyakarta, Indonesia
}

\begin{abstract}
Cinnamon (Cinnamomum spp.), an ancient spice, has been explored as a potential for medicinal purposes. Despite numerous studies about its potency in overcoming of numerous diseases, the potency as anti-cancer would be a challenge. This current article provides a review of the anticancer and chemoprevention potency of cinnamon and its major constituents: cinnamaldehyde, cinnamic acid, 2-hydroxycinnamaldehyde, 2-methoxycinnamaldehyde, and eugenol. Comprehensively, cinnamon and its constituents exhibit the anti-cancer and cancer prevention activities through various mechanisms: (I) anti-proliferation, (2) induction of cell death, (3) anti-angiogenesis, (4) antimetastasis, (5) suppression of tumor-promoted inflammation, (6) immunomodulation, and (7) modulation of redox homeostasis; both in vitro and in vivo. Moreover, cinnamon also shows the synergistic anti-cancer effect with well-known anti-cancer drugs, such as doxorubicin, which support its potency to be used as a combination chemotherapeutic (co-chemotherapeutic) agent. However, further study should be established to determine the exact target molecule(s) of cinnamon in the cancer cells.
\end{abstract}

Keywords: cinnamon, spice, cancer, anti-cancer, chemopreventive

\section{INTRODUCTION}

Cinnamon has been widely used in either the East or West parts of the world as a spice for thousands of years. Originally from Ceylon (Sri Lanka), cinnamon spreads around the world through trading and colonization (Barceloux, 2009). The genus Cinnamomum is made up of more than 250 species, which primarily cultivated in Asia and Australia. Some of the most valuable and famous species are Cinnamomum zeylanicum (Sri Lanka/Ceylon cinnamon), Cinnamomum cassia (China cinnamon), and Cinnamomum burmanni (Indonesia cinnamon).

Cinnamon bark is the most common part to be used from a cinnamon tree. Numerous studies have been conducted to reveal the biological activity of cinnamon. One of the most well studied is the potency of cinnamon as an anti-diabetic agent. As reviewed by Ranasinghe, et al. (2012), C. zeylanicum showed an anti-diabetic activity in vitro, such as stimulating cellular glucose uptake by membrane translocation of glucose transporter-4, stimulating glucose metabolism and glycogen synthesis; and in vivo, including reducing fasting blood glucose and increasing circulating insulin levels. Another biological activity of cinnamon is the gastro-protective effect, which is attributed to cinnamon activity as an anti-inflammatory and antiulcer agent (Yu, et al., 2012; Alqasoumi 2012). A pharmaceutical company in Indonesia, Dexa Medica, steps up the value of cinnamon by using it as the active ingredient of their drugs. Dexa Medica has formulated the standardized extract of $C$. burmanni into Inlacin ${ }^{\circledR}$ and Redacid $®$ with the indication as an anti-diabetic and gastro-protector, respectively.

Ranasinghe, et al. (2013) provided a comprehensive systematic review regarding cinnamon biological activities, including a) antimicrobial and anti-parasitic activity, b) lowering of

Submitted: Feb 20, 2018

Revised: Feb 21, 2018

Accepted: Feb 22, 2018

*Corresponding author e-mail : edy_meiyanto@ugm.ac.id 
blood glucose, blood pressure, and serum cholesterol, c) antioxidant and free-radical scavenging properties, d) inhibition of tau aggregation and filament formation (hallmarks of Alzheimer's disease), e) inhibitory effects on osteoclastogenesis, f) anti-secretagogue and anti-gastric ulcer effects, g) anti-nociceptive and antiinflammatory activity, h) wound healing properties and i) hepato-protective effects. Yet, in spite of numerous research reported the activity of cinnamon as an anti-cancer agent, to date there is no comprehensive review in this topic. Therefore, here we review the recent original research articles studying cinnamon and/or its constituent effect on various models of cancer. This review article aims to provide an overview regarding the activity cinnamon and its chemical constituents as an anti-cancer and chemopreventive agent. Furthermore, we discuss the molecular targets of cinnamon in cancer cells in order to provide a deeper and comprehensive understanding of cinnamon potency as an anticancer and chemopreventive agent.

\section{CONSTITUENTS OF CINNAMON BARK}

The most common method to extract the constituent of cinnamon bark is by either water extraction or distillation, yielded in aqueous extract or essential oil, respectively. Using both methods, cinnamaldehyde/ trans-cinnamaldehyde/ cinnamic aldehyde remains as the main constituent of cinnamon bark. Ding, et al. (2011) analyzed the content of cinnamon barks and twigs and found cinnamaldehyde as the most abundant marker component (average content was $86.25 \mathrm{mg} / \mathrm{g}$ ), followed by eugenol $(14.40 \mathrm{mg} / \mathrm{g})$, coumarin $(5.79$ $\mathrm{mg} / \mathrm{g})$, cinnamyl alcohol $(1.13 \mathrm{mg} / \mathrm{g})$, and cinnamic acid $(0.87 \mathrm{mg} / \mathrm{g})$.

In addition to those compounds, they also found 2-hydroxyl cinnamaldehyde, cinnamyl alcohol, and 2-methoxy cinnamaldehyde in the sample. Another study by Kamaliroosta, et al. (2012) found that the essential oil of cinnamon barks (C. zeylanicum) comprises of cinnamic aldehyde $(62.09 \%)$, para-methoxycinnamic aldehyde (11.56\%), alpha-copaene (6.98\%), and alphamuurolene $(4.32 \%)$ as the main constituents. In this current article, we discuss several unique constituents of cinnamon bark that have been studied as the anti-cancer and chemopreventive agents, which are cinnamaldehyde, cinnamic acid, 2hydroxycinnamaldehyde,

2-metho-<smiles>O=C/C=C/c1ccccc1</smiles><smiles>O=C/C=C/c1ccccc1O</smiles>

2-hydroxycinnamaldehyde<smiles>O=C(O)/C=C/c1ccccc1</smiles>

Cinnamic acid<smiles>COc1ccccc1/C=C/C=O</smiles>

2-methoxycinnamaldehyde<smiles>C=CCc1ccc(O)c(OC)c1</smiles>

Eugenol

Figure I. Chemical constituents of cinnamon bark that have been studied as the anticancer and chemopreventive agent 


\section{ANTI-CANCER CINNAMON BARK \\ ACTIVITIES OF}

Cancer is a disease with multiple physiological changes due to the complex genetic alteration. A renowned review paper by Hanahan and Weinberg in 2011 summarized the characteristics of cancer cells as following: (1) sustaining proliferative signaling; (2) evading growth suppressor; (3) avoiding immune destruction; (4) enabling replicative immortality; (5) tumorpromoting inflammation; (6) activating invasion and metastasis; (7) inducing angiogenesis; (8) genome instability and mutation; (9) resisting cell death; and (10) deregulating cellular energetics (Hanahan and Weinberg, 2011). In general, cancer cells are able to grow uncontrollably, escaping cell death and immune destruction, invade tissues and metastasize, induce angiogenesis, promote inflammation in surrounding tissues, and has aberrant cell metabolism. In addition to those mentioned features, scientists also consider redox homeostasis in the cancer cells to be a target for cancer therapy. Redox homeostasis is the capacity of cells to manage the electrochemical potential inside the cells, which mostly related to the cells' oxidative state (Wondrak, et al., 2009). Combination chemotherapy (cochemotherapy) is also in well-known strategy that works by combining two or more anti-cancer or chemopreventive agent in order to increase the efficacy of cancer therapy and/or alleviate the side effect of cancer therapy.

Researchers have conducted myriad studies on the anti-cancer potency of cinnamon bark. The summary of anti-cancer activities of extract and/or essential oil of cinnamon bark is available in the Table 1; while the summary of anti-cancer activities of the chemical constituents of cinnamon bark is available in the Table 2.

Table I. Anti-cancer activity of cinnamon extract/essential oil

\begin{tabular}{|c|c|c|c|}
\hline $\begin{array}{l}\text { Preparation of } \\
\text { extract/ } \\
\text { essential oil }\end{array}$ & $\begin{array}{c}\text { Physiology/cellular effect } \\
\text { as anti-cancer }\end{array}$ & Molecular event(s) & Reference \\
\hline \multirow{4}{*}{$\begin{array}{l}\text { aqueous extract of } \\
\text { C. cassia (AEC) }\end{array}$} & $\begin{array}{l}\text { - } \quad \text { AEC inhibits melanoma } \\
\text { progression in vivo } \\
\text { - } A E C \text { inhibits tumor angiogenesis in } \\
\text { vivo } \\
\text { - } \quad \text { AEC increases the cytolytic activity } \\
\text { of CD8+ T cells in tumor draining } \\
\text { lymph nodes. }\end{array}$ & $\begin{array}{l}\text { Down-regulates the } \\
\text { level of pro- } \\
\text { angiogenic factors } \\
\text { (EGF, VEGF- } \alpha, \text { TGF- } \\
\text { b, and FGF) } \\
\text { Down-regulates the } \\
\text { level of HIF-I } \alpha \text { and } \\
\text { COX-2 }\end{array}$ & Kwon, et al. (2009) \\
\hline & $\begin{array}{l}\text { - AEC inhibits tumor cell growth (in } \\
\text { HeLa, Caco-2, EL4, and Clone M3 } \\
\text { cell lines) in vitro, but not in normal } \\
\text { cells (primary mouse lymphocyte) } \\
\text { - AEC inhibits tumor cell growth in } \\
\text { vivo }\end{array}$ & 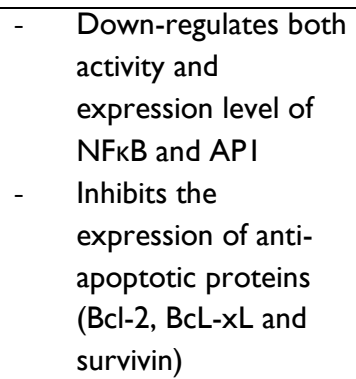 & Kwon, et al. (20I0) \\
\hline & $\begin{array}{l}\text { - } A E C \text { inhibits SiHa cervical cancer } \\
\text { cells growth and migration } \\
\text { - } \quad \text { AEC induces apoptosis in } \mathrm{SiHa} \\
\text { cells }\end{array}$ & 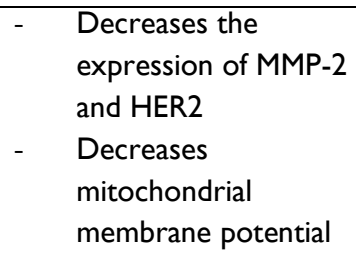 & Koppikar, et al. (20I0) \\
\hline & $\begin{array}{ll}- & \text { AEC inhibits angiogenesis in } \\
& \text { HUVEC cells and zebrafish embryo }\end{array}$ & $\begin{array}{ll}- & \text { Decreases TPA- } \\
\text { induced PKC } \alpha \text { and } \\
\text { PKC } \gamma \text { mRNA } \\
\text { expression }\end{array}$ & Bansode, et al. (2013) \\
\hline
\end{tabular}




\begin{tabular}{|c|c|c|c|}
\hline & & $\begin{array}{l}\text { Decreases VEGFRI } \\
\text { and VEGFR2 mRNA } \\
\text { expression } \\
\text { - } \quad \text { Inhibits the } \\
\text { phosphorylation of } \\
\text { MAPK signaling } \\
\text { cascade }\end{array}$ & \\
\hline $\begin{array}{l}\text { aqueous extract of } \\
\text { Cinnamomum } \\
\text { Burmannii } \\
\text { (AEB) }\end{array}$ & 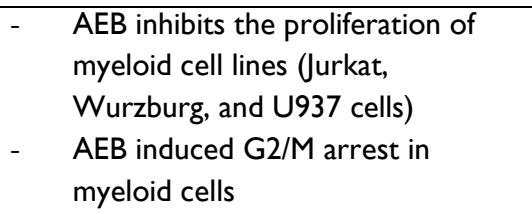 & $\begin{array}{l}\text { Decreases the } \\
\text { intracellular } \\
\text { phosphatase activity }\end{array}$ & Schoene, et al. (2005) \\
\hline $\begin{array}{l}\text { aqueous extract of } \\
\text { Cinnamomum } \\
\text { zeylanicum } \\
\text { (AEZ) }\end{array}$ & $\begin{array}{l}\text { - AEZ shows higher cytotoxic } \\
\text { activity compared to commercial } \\
\text { cinnamaldehyde (at comparable } \\
\text { concentraton of cinnamaldehyde) } \\
\text { in various cancer cell lines } \\
\text { - In the toxic dose, AEZ shows } \\
\text { significant higher cytotoxicity in } \\
\text { cancer cells rather than in normal } \\
\text { cell }\end{array}$ & Not determined & Singh, et al. (2009) \\
\hline $\begin{array}{l}\text { Essential oil of } \\
\text { Cinnamomum } \\
\text { burmannii } \\
\text { (EOB) }\end{array}$ & $\begin{array}{l}\text { EOB shows cytotoxicity and } \\
\text { induces apoptosis in T47D breast } \\
\text { cancer cells and HeLa cells } \\
\text { EOB shows synergist effect with } \\
\text { doxorubicin in T47D cells and with } \\
\text { cisplatin in HeLa cells }\end{array}$ & Not determined & $\begin{array}{l}\text { Anjarsari, et al. (20l3) } \\
\text { Larasati, et al. (20|4) }\end{array}$ \\
\hline $\begin{array}{l}\text { Ethanol extract of } \\
\text { cinnamon (EC) }\end{array}$ & $\begin{array}{l}\text { EC inhibits the proliferation of HT- } \\
29 \text { colon cancer cells, but not } \\
\text { CCD-I I } 2 \text { CoN normal colon cells }\end{array}$ & $\begin{array}{ll}- & \text { Decreases the } \\
\text { production of } \mathrm{PGE}_{2} \\
\text { - } \text { Decreases the } \\
\text { expression of } \\
\text { COX-2 }\end{array}$ & Lee, et al. (2006) \\
\hline
\end{tabular}

API: activator protein I; Bcl-2: B-cell lymphoma 2; Bcl-xL: B-cell lymphoma-extra large; COX-2: cyclooxygenase 2; EGF: epidermal growth factor; FGF: fibroblast growth factor; HER2: human epidermal growth factor receptor 2; HUVEC: human umbilical vein endothelial cells; MAPK: mitogen-activated protein kinase; MMP-2: matrix metalloproteinase-2; mRNA: messenger ribonucleic acid; NFKB: nuclear factor

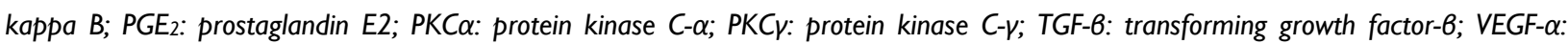
vascular endothelial growth factor- $\alpha$; VEGFRI: vascular endothelial growth factor receptor I; VEGFR2: vascular endothelial growth factor receptor 2 .

Table 2. Anti-cancer activity of the constituents of cinnamon bark

\begin{tabular}{|c|c|c|c|}
\hline Compound & $\begin{array}{c}\text { Physiology/cellular effect } \\
\text { as anti-cancer }\end{array}$ & Molecular event(s) & Reference \\
\hline \multirow{3}{*}{$\begin{array}{l}\text { Cinnamaldehyde / } \\
\text { trans- } \\
\text { cinnamaldehyde/ } \\
\text { cinnamic aldehyde/ } \\
\text { (CA) }\end{array}$} & $\begin{array}{l}\text { - } \quad \text { CA inhibits the proliferation and } \\
\text { induces apoptosis in HL60 pro- } \\
\text { myelocytic leukemia cells }\end{array}$ & $\begin{array}{ll}- & \text { Increases ROS } \\
& \text { intracellular }\end{array}$ & Ka, et al. (2003) \\
\hline & $\begin{array}{l}\text { - CA exhibits cytotoxicity in Jurkat } \\
\text { and U397 leukemia cells, but not in } \\
\text { normal T cells and macrophages } \\
\text { CA induces G2/M arrest in Jurkat } \\
\text { and U397 leukemia cells }\end{array}$ & Not determined & Fang, et al. (2004) \\
\hline & 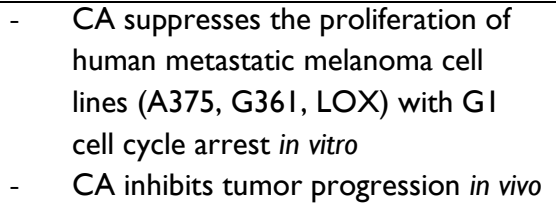 & $\begin{array}{ll}- & \text { Increases intracellular } \\
& \text { ROS } \\
\text { - } & \text { Up-regulates HMOXI, } \\
\text { SRXNI, TXNRDI, } \\
\text { CDKNIA }\end{array}$ & Cabello, et al. (2009) \\
\hline
\end{tabular}




\begin{tabular}{|c|c|c|c|c|}
\hline- & $\begin{array}{l}\text { CA treatment at low micromolar } \\
\text { concentrations up-regulates } \\
\text { oxidative stress response gene } \\
\text { expression in A375 melanoma } \\
\text { cells }\end{array}$ & - & $\begin{array}{l}\text { Inhibits of NFKB } \\
\text { transcriptional activity } \\
\text { and TNF } \alpha \text {-induced IL-8 } \\
\text { production }\end{array}$ & \\
\hline- & $\begin{array}{l}\text { CA induces apoptosis in } \mathrm{K} 562 \\
\text { leukemia cells } \\
\text { CA exhibits synergist cytotoxicity } \\
\text { with cytokine-induced killer (CIK) } \\
\text { cells }\end{array}$ & - & $\begin{array}{l}\text { Up-regulates Fas } \\
\text { expression } \\
\text { Decreases } \\
\text { mitochondrial } \\
\text { transmembrane } \\
\text { potential }\end{array}$ & Zhang, et al. (20I0) \\
\hline- & $\begin{array}{l}\text { CA inhibits the proliferation and } \\
\text { induces apoptosis in HCTII } 6 \text { colon } \\
\text { cancer and MCF- } 7 \text { breast cancer } \\
\text { cells } \\
\text { CA induces G2/M arrest in HCTII6 } \\
\text { cells }\end{array}$ & - & $\begin{array}{l}\text { Inhibits thioredoxin } \\
\text { reductase enzymatic } \\
\text { activity } \\
\text { Induces Nrf2 activity }\end{array}$ & Chew, et al. (20I0) \\
\hline- & $\begin{array}{l}\text { CA exhibits cytotoxicity in colon } \\
\text { cancer cells } \\
\text { Pre-treatment with CA attenuates } \\
\mathrm{H}_{2} \mathrm{O}_{2} \text {-induced genotoxicity in colon } \\
\text { cancer cells }\end{array}$ & - & $\begin{array}{l}\text { Up-regulates the Nrf2 } \\
\text { activity } \\
\text { Up-regulates heme } \\
\text { oxygenase I (HO-I) } \\
\text { and } \gamma \text {-glutamylcysteine } \\
\text { synthetase ( } \gamma \text {-GCS, } \\
\text { catalytic subunit) } \\
\text { Up-regulates cellular } \\
\text { glutathione level }\end{array}$ & $\begin{array}{l}\text { Wondrak, et al. } \\
(2010)\end{array}$ \\
\hline- & $\begin{array}{l}\text { CA induces apoptosis and G2/M } \\
\text { arrest in HCTI } 16 \text { cells } \\
\text { CA induces tubulin aggregation }\end{array}$ & - & $\begin{array}{l}\text { Down-regulates CdkI } \\
\text { and cdc25 } \\
\text { Up-regulates the level } \\
\text { of cyclin B }\end{array}$ & Nagle, et al. (20I2) \\
\hline- & $\begin{array}{l}\text { CA inhibits the proliferation and } \\
\text { induces apoptosis in HepG2 and } \\
\text { Hep3B hepatoma cells }\end{array}$ & - & $\begin{array}{l}\text { Decreases the } \\
\text { expression of cyclin DI, } \\
\text { PCNA, and Bcl-2 } \\
\text { Induces the expression } \\
\text { of p27 and p2I } \\
\text { Activates caspase-3 } \\
\text { Inhibits JAK2- } \\
\text { STAT3/STAT5 signaling } \\
\text { pathway }\end{array}$ & Chuang, et al. (20I2) \\
\hline - & $\begin{array}{l}\text { CA shows higher cytotoxicity than } \\
\text { cisplatin in C666-I human } \\
\text { nasopharyngeal carcinoma (NPC) } \\
\text { cells } \\
\text { CA shows synergist anti-proliferative } \\
\text { effect with cisplatin }\end{array}$ & - & $\begin{array}{l}\text { Induces } \\
\text { phosphorylation of } \\
\text { histone } \mathrm{H} 2 \mathrm{AX} \\
\text { Induces activation of } \\
\text { caspase- } 3 / 7\end{array}$ & Daker, et al. (2013) \\
\hline - & $\begin{array}{l}\text { CINN inhibits the invasiveness of } \\
\text { A549 lung adenocarcinoma cells } \\
\text { without significant effect on the } \\
\text { adhesive activity of cells } \\
\text { cis-cinnamic acid shows higher } \\
\text { activity than trans-cinnamic acid }\end{array}$ & - & $\begin{array}{l}\text { Inhibits the activity of } \\
\text { MMP-2 and MMP-9 }\end{array}$ & Yen, et al. (20II) \\
\hline - & $\begin{array}{l}\text { CINN pre-treatment reduces } \\
\text { cyclophosphamide-induced } \\
\text { myelosuppression and oxidative } \\
\text { stress in bone marrow }\end{array}$ & - & $\begin{array}{l}\text { Reduces lipid } \\
\text { peroxidation } \\
\text { Increases the activity of } \\
\text { antioxidant enzymes } \\
\text { (superoxide dismutase, } \\
\text { catalase and }\end{array}$ & Patra, et al. (20I2) \\
\hline
\end{tabular}




\begin{tabular}{|c|c|c|c|}
\hline & & $\begin{array}{l}\text { glutathione-S- } \\
\text { transferase) }\end{array}$ & \\
\hline- & $\begin{array}{l}\text { CINN inhibits the invasiveness of } \\
\text { A549 lung adenocarcinoma cells }\end{array}$ & $\begin{array}{ll}- & \text { Inhibits the activity of } \\
\text { MMP-2 and MMP-9 } \\
\text { - } \quad \text { Increases the levels of } \\
\text { PAI-2 to suppress uPA } \\
\text { activity } \\
\text { - Supresses NFKB and } \\
\text { AP-I }\end{array}$ & Tsai, et al. (20/3) \\
\hline- & $\begin{array}{l}\text { CINN inhibits the proliferation of } \\
\text { lung cancer stem cells } \\
\text { CINN induces GI arrest and } \\
\text { apoptosis in lung cancer stem cells } \\
\text { CINN increases the sensitivity of } \\
\text { lung cancer stem cells toward } \\
\text { cisplatin and paclitaxel } \\
\text { CINN promotes differentiation and } \\
\text { reduces the invasive ability of lung } \\
\text { cancer stem cells }\end{array}$ & $\begin{array}{ll}- & \text { Down-regulates } \mathrm{Bcl}-2 \\
& \text { and survivin } \\
- & \text { Up-regulates Bax }\end{array}$ & Huang, et al. (20I2) \\
\hline 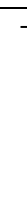 & $\begin{array}{l}\text { CINN induces cytotoxicity and } \\
\text { apoptosis in human melanoma cell } \\
\text { line (HT-I44) }\end{array}$ & $\begin{array}{l}\text { - Increases the activation } \\
\text { of caspase- } 3 \text { and } \\
\text { expression of } \mathrm{Bax} \\
\text { - } \text { Decreases the } \\
\text { expression of } \mathrm{Bcl}-2\end{array}$ & $\begin{array}{l}\text { de Oliveira Niero and } \\
\text { Machado-Santelli } \\
(2013)\end{array}$ \\
\hline 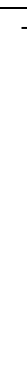 & $\begin{array}{l}\text { 2-HCA induces apoptosis in SW620 } \\
\text { colon cancer cells }\end{array}$ & $\begin{array}{ll}\text { - } & \text { 2-HCA binds to } 5 \\
\text { subunits of proteasome } \\
\text { complex and inhibits } \\
\text { the activity of } \\
\text { proteasome } \\
\text { - } \quad \text { Induces ER stress } \\
\text { - } \quad \text { Decreases } \\
\text { mitochondrial } \\
\text { membrane potential }\end{array}$ & Hong, et al. (2007) \\
\hline 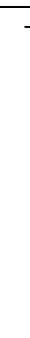 & $\begin{array}{l}\text { 2-HCA inhibits the growth and } \\
\text { induces apoptosis in SW } 620 \text { human } \\
\text { colon cancer cell }\end{array}$ & $\begin{array}{ll}- & \text { Inhibits AP-I } \\
\text { transcriptional activity } \\
\text { and DNA binding } \\
\text { activity } \\
\text { - } \quad \text { Inhibits c-Jun and c-Fos } \\
\text { expression } \\
\text { - } \\
\text { Increases caspase-3 and } \\
\text { decreases Bcl-2 }\end{array}$ & Lee, et al. (2007) \\
\hline- & $\begin{array}{l}2-\mathrm{HCA} \text { inhibits oral cancer growth in } \\
\text { vitro and in vivo } \\
2-\mathrm{HCA} \text { induces apoptosis and cell } \\
\text { cycle arrest in } \mathrm{G} 2 / \mathrm{M} \text { phase }\end{array}$ & $\begin{array}{l}\text { Increases the levels of } \\
\text { cleaved PARP and } \\
\text { caspase- } 3\end{array}$ & Kim, et al. (2010) \\
\hline- & $\begin{array}{l}\text { 2-HCA inhibits the proliferation of } \\
\text { HCTII } 6 \text { colon cancer and MCF-7 } \\
\text { breast cancer cells }\end{array}$ & $\begin{array}{l}\text { Inhibits thioredoxin } \\
\text { reductase enzymatic } \\
\text { activity }\end{array}$ & Chew, et al. (20I0) \\
\hline - & $\begin{array}{l}\text { 2-HCA inhibits breast cancer cell } \\
\text { migration without affecting viability } \\
\text { 2-HCA inhibits EGF-induced EMT in } \\
\text { breast cancer cells } \\
\text { 2-HCA inhibits lung metastasis and } \\
\text { micromestastasis in vivo }\end{array}$ & $\begin{array}{ll}- & \text { Increases E-cadherin } \\
\text { transcription } \\
- & \text { Suppresses the protein } \\
& \text { level of Snail } \\
- & \text { Induces KLFI7 } \\
\text { expression } \\
-\quad & \text { Suppresses SP-I and ID- } \\
\text { I expression }\end{array}$ & Ismail, et al. (20|3) \\
\hline
\end{tabular}




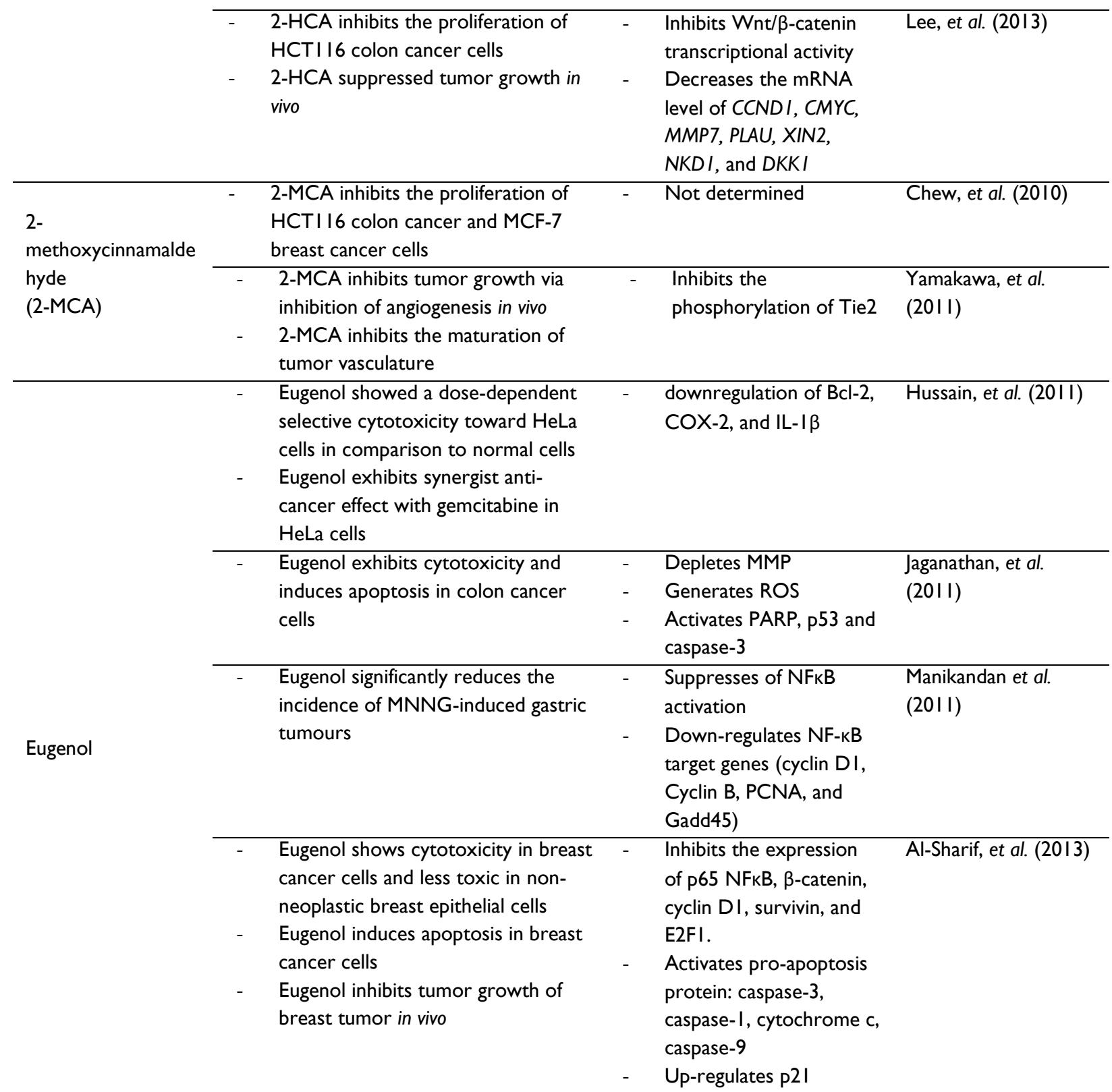

API: activator protein I; Bcl-2: B-cell lymphoma 2; Bax: Bcl-2 Associated X; COX-2: cyclooxygenase 2; CCND I: cyclin DI (gene); CdkI: cyclin dependent kinase I; CDKNIA: cyclin-dependent kinase inhibitor IA (gene); DKKI: Dickkopf-related protein I; DNA: deoxyribonucleic acid; EGF: epidermal growth factor; EMT: epithelial-mesenchymal transition; ER: endoplasmic reticulum; E2FI: E2 factortranscription factor 1; GADD45: growth arrest and DNA-damage-inducible protein 45 alpha; $\gamma$-GCS: $\gamma$-glutamylcysteine synthetase; HOI: heme oxygenase I (protein); HMOXI: heme oxygenase-I (gene); $\mathrm{H}_{2} \mathrm{O}_{2}$ : hydrogen peroxide; Id-I: inhibitor of differentiation/DNA binding; IL-8: interleukin 8; IL-I8: interleukin 18; JAK: Janus tyrosine Kinase; KLFI7: Kruppel Like Factor 17; MMP-2: matrix metalloproteinase-2; MMP-9: matrix metalloproteinase-9; MMP7: matrix metalloproteinase-7; MNNG: N-methyl-N'-nitro-Nnitrosoguanidine; NKD: naked cuticle homolog I; NFKB: nuclear factor kappa B; Nrf2: nuclear factor erythroid 2 (NFE2)-related factor 2; PAI2: plasminogen activator inhibitor-2; PARP: poly (ADP-ribose) polymerase; PCNA: proliferating cell nuclear antigen; PLAU: plasminogen activator, urokinase; ROS: reactive oxygen species; SRXNI: sulfiredoxin I homolog; STAT: Signal Transducer and Activator of Transcription; Sp I: specificity protein I; TNF $\alpha$ : tumor necrosis factor $\alpha$; TXNRDI: thioredoxin reductase I; uPA: urokinase-type plasminogen activator; VEGFR2: vascular endothelial growth factor receptor 2.
ANTI-PROLIFERATIVE
AND
PRO-

\section{APOPTOSIS}
The most well-known and traditional anti- cancer drugs act as tumor cell growth suppressor
(anti-proliferative) and cell death-inducer (pro- apoptosis). The activity of cinnamon bark and/or its constituents as the anti-proliferative and pro- apoptosis are presented below. 


\section{Cinnamon extract/essential oil}

Aqueous extract of $C$. cassia (AEC) exhibits an anti-proliferative effect in vitro and in vivo in various models of cancer, such as melanoma, cervical cancer, and colon cancer (Kwon, et al., 2009; Kwon, et al., 2010; Koppikar, et al., 2010). Koppikar, et al. (2010) found that AEC increases intracellular levels of calcium, leads to perturbation of mitochondrial membrane potential, which ultimately induces apoptosis in SiHa cervical cancer cells. Another study by Kwon, et al. (2010) found that AEC also suppresses the expression of antiapoptotic proteins (e.g., Bcl-2, BcL-xL, and survivin) by down-regulating the activity and expression level of $\mathrm{NF \kappa B}$ and AP1 proteins.

Another species of cinnamon, C. burmannii, also exhibits anti-cancer potency. Schoene, et al. (2005) reported that the aqueous extract of $C$. burmannii (AEB) inhibits the proliferation of some myeloid cell lines: Jurkat, Wurzburg, and U937 cells). AEB decreases the intracellular phosphatase activity that later induces cell cycle arrest in G2/M phase. In addition, the essential oil of $C$. burmannii shows cytotoxicity and induces apoptosis in T47D breast cancer cells (Anjarsari, et al., 2013).

Interestingly, cinnamon bark shows selective anti-proliferative effect towards cancerous cells rather than normal (non-cancerous) cells. Lee, et al. (2006) reported that the extract of cinnamon inhibits the proliferation of HT-29 colon cancer cells, but not CCD-112CoN normal colon cells. A similar result was reported by Kwon, et al. (2010); AEC inhibits tumor cell growth (in HeLa, Caco-2, EL4, and Clone M3 cell lines) in vitro, but not in normal cells (primary mouse lymphocyte). Moreover, Singh, et al. (2009) reported that the aqueous extract of $C$. zeylanicum (AEZ) shows significant higher cytotoxicity in cancer cells rather than in the normal cells. This selectivity feature is very important for the anti-cancer drugs that hopefully the drugs have minimum side effect for the clinical therapy.

\section{Cinnamaldehyde}

Cinnamaldehyde exhibits anti-proliferative activity in various cancer cells, including leukemia melanoma, colon cancer, nasopharyngeal carcinoma, breast cancer, and hepatoma in vitro ( $\mathrm{Ka}$, et al., 2003; Fang, et al., 2004; Cabello, et al., 2009; Chew, et al., 2010; Wondrak, et al., 2010; Chuang, et al., 2012; Daker, et al., 2013). Moreover, cinnamaldehyde also suppresses tumor cell progression in vivo in the mouse model of cancer (Cabello, et al., 2009).

Suppression of cancer cell growth can be attributed to the inhibition of cell division (cell cycle) and/or induction of cell death. Cinnamaldehyde induces G1 cell cycle ar,rest in melanoma cells (Cabello, et al., 2009). However, other studies found that cinnamaldehyde induces G2/M arrest in Jurkat and U397 leukemia cells; as well as HCT116 colon cancer cells (Fang, et al., 2004; Chew, et al., 2010; Nagle, et al., 2012). Nagle, et al. (2012) reported several molecular events by which cinnamaldehyde induces G2/M arrest. Cinnamaldehyde down-regulates protein Cdk1 and cdc25, which are the important proteins for $\mathrm{G} 2 / \mathrm{M}$ progression. Cyclin $\mathrm{B}$, an important protein that should be diminished during G2/M progression, was sustained by cinnamaldehyde. Moreover, cinnamaldehyde induces tubulin aggregation; hence the cells in $\mathrm{G} 2 / \mathrm{M}$ phase can not further divide themselves.

In addition to the induction of cell cycle arrest, cinnamaldehyde induces apoptosis in leukemia, colon cancer, breast cancer, hepatoma, and human nasopharyngeal carcinoma (NPC) cells (Ka, et al., 2003; Zhang, et al., 2010; Chew, et al., 2010; Chuang, et al., 2012; Daker, et al., 2013). Several mechanisms contribute to the apoptosis effect of cinnamaldehyde, such as generation of intracellular ROS (Ka, et al., 2003), up-regulation of cell death surface receptor Fas (Zhang, et al., 2010), and modulation of pro- and anti-apoptosis proteins (Chuang, et al., 2012; Daker, et al., 2013).

\section{Cinnamic acid}

Cinnamic acid exhibits cytotoxicity and induces apoptosis in HT-144 human melanoma cells (de Oliveira Niero and Machado-Santelli, 2013). Cinnamic acid up-regulates the activity of caspase- 3 and expression of Bax, the pro-apoptotic proteins; while decreasing the expression of $\mathrm{Bcl}-2$, an anti-apoptotic protein (de Oliveira Niero and Machado-Santelli, 2013). Interestingly, cinnamic acid also exhibits anti-cancer activity in the cancer stem cells. Huang, et al. (2012) examined the effect of cinnamic acid in lung cancer stem cells. Cinnamic acid inhibits the proliferation as well as induces apoptosis and G1 arrest in the lung cancer stem cells. 


\section{2-hydroxycinnamaldehyde (2-HCA)}

2- HCA shows the anti-proliferative activity in colon cancer and oral cancer; as well as induces apoptosis in those cells (Hong, et al., 2007; Lee, et al., 2007; Kim, et al., 2010). Lee, et al. (2013) also showed that 2-HCA inhibits tumor progression in vivo. Hong, et al. (2007) found that 2hydroxycinnamaldehyde decreases mitochondrial membrane potential, resulting in cell apoptosis. Lee, et al. (2007) showed that 2-hydroxycinnamaldehyde modulates the pro- and anti-apoptotic protein levels, such as caspase-3 and Bcl-2. In addition to apoptosis, 2-HCA induces cell cycle arrest in G2/M phase (Kim, et al., 2010). 2- HCA also inhibits the transcriptional and DNA binding activity of AP-1, a transcriptional factor important for cancer cell growth (Lee, et al., 2007).

2- HCA is the only constituent of cinnamon bark that has been studied for its direct protein target in cancer cells. Hong, et al. (2007) performed a pull-down assay and found that 5 subunits of proteasome complex interacted physically with 2hydroxycinnamaldehyde. This interaction inhibits the activity of proteasome, resulting in various perturbations inside the cancer cells, leading to apoptosis. Even though not yet elucidating the direct binding site, Hong and colleague suggests that 2hydroxycinnamaldehyde is an effective proteasome inhibitor by inactivating multiple catalytic activities of proteasome. Another possible target of 2-HCA is the Wnt/ $\beta$-catenin pathway. Lee, et al. (2013) showed that 2-HCA inhibits the transcriptional activity of $\mathrm{Wnt} / \beta$-catenin. This inhibition results in down-regulation of various gene targets of $\mathrm{Wnt} / \beta$ catenin signaling, such as $C C N D 1, C M Y C, M M P 7$, $P L A U, X I N 2, N K D 1$, and DKK1, which are the proteins that play role in cell proliferation, survival, and motility.

\section{2-methoxycinnamaldehyde (2-MCA)}

2-MCA inhibits the proliferation of HCT116 colon cancer cells (Chew, et al., 2010). However, further study is needed to elucidate its exact molecular mechanism.

\section{Eugenol}

Although not only found in cinnamon bark, eugenol is one of the major constituents of cinnamon. An interesting feature of eugenol is that it selectively toxic to cancer cells, but less toxic in normal cells. Hussain, et al. (2011) reported that eugenol exhibits cytotoxicity in HeLa cervical cancer cells, but not in normal cells. Another study by Al-Sharif, et al. (2013) showed that eugenol is more toxic in the breast cancer cells rather than in non-neoplastic breast epithelial cells. Eugenol induces apoptosis in cervical cancer, colon cancer, and breast cancer cells in vitro (Hussain, et al., 2011; Jaganathan, et al., 2011; Al-Sharif, et al., 2013). Eugenol also exhibits anti-tumor activity in vivo, in rats developing MNNG-induced gastric tumors (Manikandan, et al., 2011) and breast cancerxenografted mice (Al-Sharif, et al., 2013).

At the molecular level, eugenol activates the pro-apoptotic proteins, such as PARP, caspase-3, caspase-1, and caspase-9; as well as up-regulates cell cycle regulator proteins p53 and p21 (Jaganathan, et al., 2011; Al-Sharif, et al., 2013). Eugenol also suppresses the expression and activation of $\mathrm{NF \kappa B}$, resulting in down-regulation of NF- $\mathrm{kB}$ target genes (cyclin D1, Cyclin B, PCNA, Gadd45) (Manikandan, et al., 2011).

\section{ANGIOGENESIS}

To supply the nutrition and oxygen for their growth, cancer cells form blood vessels in a process called angiogenesis. Hypoxia, a condition in which cancer cells lack of oxygen, plays a key role in angiogenesis; which then activates VEGF signaling as the important mediator of angiogenesis (Hanahan and Weinberg, 2011). The activity of cinnamon bark and/or its constituents as an anti-angiogenic agent is discussed below.

\section{Cinnamon extract/essential oil}

Kwon, et al. (2009) reported that AEC inhibits tumor angiogenesis in vivo and downregulates the level of pro-angiogenic factors (e.g., EGF, VEGF-a, TGF-b, and FGF). They also found that AEC decreases the level of HIF-1 $\alpha$, a transcription factor that is active in hypoxia condition and promote tumor angiogenesis. Another study by Bansode, et al. (2013) reported that AEC inhibits the formation of blood vessels in HUVEC cells and zebrafish embryo. More over, Bansode, et al. showed that AEC inhibits the expression of PKC and inactivates MAPK/Akt signaling, which turns out decreases the expression of VEGFR. 


\section{2-methoxycinnamaldehyde (2-MCA)}

Yamakawa, et al. (2011) showed that 2-MCA suppresses tumor growth in vivo by inhibiting angiogenesis. Moreover, 2-MCA inhibits the maturation of blood vessels in the tumor (tumor vasculature). At the molecular level, 2-MCA inhibits the phosphorylation of Tie2, a vascular growth factor that is overexpressed in various tumors and induces angiogenesis.

\section{METASTASIS}

In the onset of cancer, cancer cells starts to grow in the certain part of the body and become much more harmful once they spread to the other parts of the body, in a process called metastasis (Hanahan and Weinberg, 2011). The metastasis process consists of two steps: invasion and migration. Matrix-metalloproteinase protein (MMP) family mediates these processes by degrading the extracellular matrix (ECM) proteins of the cells, make it possible for cancer cells to sneak out their original place and migrate to other parts of the body (Deryugina and Quigley, 2006). The activity of cinnamon bark and/or its constituents as an antimetastatic agent is presented below.

\section{Cinnamon extract/essential oil}

Koppikar, et al. (2010) found that AEC decreases the expression of MMP-2, both the mRNA and protein level, in $\mathrm{SiHa}$ cervical cancer cells. Furthermore, AEC also down-regulates the level of HER-2 protein, an important marker in cervical cancer related to the invasion capacity of the tumor cells.

\section{Cinnamic acid}

Yen, et al. (2011) and Tsai, et al. (2013) reported that cinnamic acid inhibits the invasive ability of A549 lung adenocarcinoma cells. Cinnamic acid decreases the mRNA level and activity of MMP-2 and MMP-9, as well as suppresses the activity of $\mathrm{NF \kappa B}$ and AP-1 (Tsai, et al., 2013). Moreover, cinnamic acid also reduces the invasive ability of lung cancer stem cells (Huang, et al., 2013). Interestingly, the cis form of cinnamic acid exhibits a better anti-metastatic activity compared to the trans-cinnamic acid (Yen, et al., 2011).

\section{2-hydroxycinnamaldehyde (2-HCA)}

Ismail, et al. (2013) reported the potency of 2HCA as an anti-metastatic agent. They showed that sub-toxic dose of 2-HCA inhibits breast cancer cell migration in vitro. 2-HCA also inhibits epidermal growth factor (EGF)-induced epithelialmesenchymal transition (EMT) in breast cancer cells. In vivo, 2-HCA is able to inhibit lung metastasis and suppress micro-metastasis.

At the molecular level, 2-HCA suppresses the protein level of Snail, a transcriptional repressor of E-cadherin. Therefore, the transcription of Ecadherin, a protein important protein for cell-cell adhesion, is increased; resulting in the stronger cellcell integrity. Moreover, 2-HCA induces KLF17 expression. KLF17 is a repressor of Id-1, a protein that increases the invasion of breast cancer cells. Consequently, the 2-HCA decreases the expression of Id-1 and inhibits breast cancer invasion.

\section{TUMOR-PROMOTED INFLAMMATION}

It was thought that the immune cells found in the cancerous tissues aim to eradicate cancer cells inside the tissue. It turns out that those immune cells promote inflammation within the tumor. That inflammation then provides the tumor microenvironment with various bioactive molecules, including growth factors and pro-angiogenic factors (Hanahan and Weinberg, 2011). Inflammation also plays an important role in tumor initiation. Therefore, an anti-inflammatory agent has the potency to be developed as an anti-cancer and chemopreventive agent. The activity of cinnamon bark and/or its constituents as an anti-inflammatory agent is discussed below.

\section{Cinnamon extract/essential oil}

Kwon, et al. (2010) reported that AEC downregulates the activity of $\mathrm{NF \kappa B}$, an important protein for inflammation. In addition, Lee, et al. (2006) reported that the ethanol extract of cinnamon decreases the production of $\mathrm{PGE}_{2}$ and the expression of COX-2, two important mediators of inflammation.

\section{Cinnamaldehyde}

Several studies showed the anti-inflammatory activity of cinnamaldehyde in models other than 
cancer cells. Kim, et al. (2007) showed that cinnamaldehyde inhibits the activation of NFKB via three signal transduction pathways: NIK/IKK, ERK, and p38 MAPK. Cinnamaldehyde also blocks IL-1 $\beta$ induced $\mathrm{PGE}_{2}$ production in the mouse cerebral microvascular endothelial cell (Ma, et al., 2008) and mouse macrophage RAW264.7 cells (Zhang, et al., 2012). Zhang, et al. also reported that cinnamaldehyde suppresses the expression of PGEsynthase-1 (mPGES-1), an important inducer of $\mathrm{PGE}_{2}$ production.

\section{IMMUNOMODULATION}

The immune system is very important for cancer elimination as it can help to fight cancer cells with no toxicity to normal tissue. However, the problem arises as the eternal mutation in cancer cells gives them the ability to evade the immune system. Therefore, scientists develop some strategies to utilize the components of immune system as cancer therapy, such as by directly targeting specific antigens expressed by cancer cells or targeting the immune system in the tumor microenvironment, such as cytokines, suppressors of Treg or MDSC activity, or antibodies that modulate T-cell activity (Finn, et al., 2012).

Cinnamon extract is able to modulate the activity of $\mathrm{T}$ cells, the cytotoxic immune cells. AEC increases the increased the anti-tumor activities of $\mathrm{CD} 8+\mathrm{T}$ cells in tumor draining-lymph nodes (Kwon, et al., 2009). Kwon and colleagues found that AEC increases the cytolytic molecules (IFN- $\Upsilon$ and TNF- $\alpha$ ) expressed in the surface of CD8 $8+\mathrm{T}$ cells. Furthermore, AEC increases the killing activity of CD8+ T cells toward cancer cells.

\section{REDOX HOMEOSTASIS IN CANCER CELLS}

Redox homeostasis plays an important yet complex role in the normal and cancer cells. The main component of redox homeostasis is the reactive oxygen species (ROS), which at the low level serves as a mediator of signal transduction; while at the high level disrupts various cell components, leading to excessive mutations and/or cell death (Sosa, et al., 2013). Therefore, the level of intracellular ROS must be regulated through a reliable redox system, which comprises of various enzymatic systems, such as glutathione redox system, thioredoxin system, and Nrf2/Keap1-ARE pathway (Wondrak, et al., 2009).

\section{Cinnamaldehyde}

$\mathrm{Ka}$, et al. (2003) reported that cinnamaldehyde increases intracellular in HL60 promyelocytic leukemia cells. Another study by Cabello, et al. (2009) also showed that cinnamaldehyde increases the intracelullar reactive oxygen species (ROS) that leads to cancer cell death. However, at the sub-toxic dose, cinnamaldehyde upregulates the oxidative stress response genes such as heme oxygenase-1 (HMOX1), sulfiredoxin 1 homolog (SRXN1), thioredoxin reductase 1 (TXNRD1). Moreover, Wondrak. et al. (2010) also reported a similar result. Wondrak and colleagues found that cinnamaldehyde is a potent activator of Nrf2 transciption. Sub-toxic concentration of cinnamaldehyde (concentration range 6-10 $\mu \mathrm{M}$ ) strongly induced the transcription of Nrf2.

\section{Cinnamic acid}

Patra, et al. (2012) showed the activity of cinnamic acid as an antioxidant. Cinnamic acid increases the activity of antioxidant enzymes, such as superoxide dismutase, catalase and glutathione-Stransferase, as well as reduces lipid peroxidation.

\section{2-hydroxycinnamaldehyde (2-HCA)}

Chew, et al. (2010) reported that 2-HCA inhibits thioredoxin reductase enzymatic activity.

\section{Eugenol}

Jaganathan, et al. (2011) reported that eugenol treatment elevates the intracellular ROS levels after $12 \mathrm{~h}$ and sustained until $48 \mathrm{~h}$. Pre-treatment of cancer cells with n-acetyl-cysteine (NAC), a powerful antioxidant, blocked eugenol-induced apoptosis. This result suggests that ROS is a key player in eugenol activity as an anti-cancer agent.

\section{CO-CHEMOTHERAPY}

Combination chemotherapy (cochemotherapy) is a strategy to increase the effectiveness of anti-cancer therapy by combining two or more anti-cancer agents. In addition, cochemotherapy also aims to reduce the side effects of a strong anti-cancer drug.

\section{Cinnamon extract/essential oil}

Anjarsari, et al. (2013) found that the essential oil of $C$. burmannii (EOB) exhibits synergistic cytotoxic effect with doxorubicin in 
T47D breast cancer cells. This essential oil of EOB also performs synergist effect with cisplatin to induce cell cycle arrest and apoptosis in HeLa cells (Larasati, et al., 2014). This synergist activity is expected to lower the dose of doxorubicin in cancer clinical therapy.

\section{Cinnamaldehyde}

Daker, et al. (2013) reported that cinnamaldehyde exhibits higher cytotoxicity than cisplatin in C666-1 human nasopharyngeal carcinoma (NPC) cells. However, cinnamaldehyde also shows a synergist anti-cancer effect when combined with cisplatin. Interestingly, cinnamaldehyde also exhibits synergist cytotoxicity with cytokine-induced killer (CIK) cells toward K562 leukemia cells (Zhang, et al., 2010). The CIK cells resemble bone marrow transplantation that is usually performed in leukemia patients. Therefore, Zhang, et al. suggest that cinnamaldehyde is compatible to be used even in the leukemia patient with former bone marrow transplantation.

\section{Cinnamic acid}

Patra, et al. (2012) reported that cinnamic acid pre-treatment protects bone marrow and hepatic cells from cyclophosphamide-induced oxidative stress. This activity of cinnamic acid occurs as it induces the activity of antioxidant enzymes, such as superoxide dismutase, catalase, and glutathione-Stransferase in the liver and bone marrow of mice, which counter the oxidative stress caused by cyclophosphamide.

\section{FUTURE PROSPECT AND STRATEGY}

After a thorough literature study, we found that the cinnamon and its constituents exhibit anticancer activities through various mechanisms, including anti-proliferation, pro-apoptosis, antiangiogenesis, anti-metastasis, inhibition of tumorinduced inflammatory, immunomodulation, modulation of redox homeostasis, and combination chemotherapy. Astonishingly, despite its extensive anti-cancer mechanism, cinnamon selectively toxic to the cancer cells rather than normal cells (Lee, et al., 2006; Kwon, et al., 2010; Singh, et al., 2009); which is an important feature for the development of anti-cancer agents with less side effect. However, in spite of the diverse molecular anti-cancer mechanisms of cinnamon constituents have been reported, only 2-hydroxycinnamaldehyde was shown to have direct protein target(s) by Hong, et al. (2007). In this time of molecular targeted therapy, we need to elucidate more the direct target(s) of cinnamon constituents by using advanced biomedical and medicinal chemistry approach in order to pinpoint the exact anti-cancer mechanism of those compounds.

It is also interesting to note that compounds in the cinnamon exhibit the different effect on the cell redox homeostasis. Eugenol and 2hydroxycinnamaldehyde were reported to act as prooxidant agents that increase the level of intracellular ROS and inhibit the cellular antioxidant enzymes (Chew, et al., 2010; Jaganathan, et al., 2011). Cinnamic acid was reported as an antioxidant agent (Patra, et al., 2012); while cinnamaldehyde was reported to promote the generation of intracellular ROS, but also induce the activation of Nrf2 pathway (Ka, et al., 2003; Cabello, et al., 2009; Wondrak, et al., 2010). An important factor to be noticed is the dose used in those studies. Wondrak, et al. (2010) used a relatively low dose of cinnamaldehyde (6-10 $\mu \mathrm{M})$ to induce the activation of $\mathrm{Nrf}$, which practically did not show the toxic effect to the cancer cells. On the other hand, Ka, et al. (2003) found that the $\mathrm{IC}_{50}$ value of cinnamaldehyde in HL60 cells is $30.7 \mu \mathrm{M}$; while Cabello, et al. (2009) showed that cinnamaldehyde $25 \mu \mathrm{M}$ exhibits cytotoxicity in the melanoma cells of $>90 \%$. These findings suggest that cinnamaldehyde exhibits bi-phasic activity in redox homeostasis of the cells: at low dose, cinnamaldehyde triggers the activation of oxidative stress response system, such as Nrf2; while at the high dose, cinnamaldehyde boosts the intracellular ROS level as one of its anti-cancer mechanism.

Whether cinnamon and its constituents possess the anti- or pro-oxidant activities is important to be acknowledged with care. There are developing evidence showed that antioxidant favors tumor growth. One of the important examples is Nrf2 pathway, the major arranger for various enzymes that protect the cells from oxidative stress (Kansanen, et al., 2013). While conventional studies believe that Nrf2 pathway is important to protect the normal cells from being cancerous; current developing studies reported that Nrf2 might play an important role in cancer chemoresistance and enhancing cancer cell growth (Shibata, et al., 2008; 
Homma, et al., 2009). As reviewed by Kansanen, et al. (2013), the Nrf2 activators are suitable to be used as in cancer prevention; while the Nrf2 inhibitors are suitable to be used in cancer therapy. Therefore, the low dose cinnamaldehyde is appropriate to be used in cancer prevention; while the higher dose is needed for its use as the anti-cancer therapy. Considering this topic, the cinnamon extract, which contains various substances in moderate dosage, is more suitable to be used as a chemopreventive agent. Meanwhile, the pure chemical constituents of cinnamon; such as cinnamaldehyde, cinnamic acid, 2-hydroxycinnamaldehyde,

2-methoxycinnamaldehyde (2-MCA), and eugenol, are potential to be developed as the anti-cancer agents.

\section{CONCLUSION}

Altogether, cinnamon and its constituent demonstrate potency to be used as the anti-cancer and chemopreventive agents. Nevertheless, further study needs to be conducted to determine the exact molecular target(s) of cinnamon constituents. Finally, a meta-analysis review with more data and statistical analysis would help to reveal the potency of cinnamon to the greater extent.

\section{REFERENCES}

Alqasoumi, S., 2012, Anti-Secretagogue and Antiulcer Effects of Cinnamon Cinnamomum Zeylanicum in Rats, J. Pharmacognosy Phytother., 4(4), 53-6I.

Al-Sharif, I., Remmal, A. and Aboussekhra, A., 2013, Eugenol Triggers Apoptosis in Breast Cancer Cells through E2FI/Survivin DownRegulation, BMC cancer, $13(1), \quad 600$, doi: I0.1 I86/ |47|-2407-13-600.

Anjarsari, E.Y., Kristina, N., Larasati, Y.A., Putri, D.D.P. and Meiyanto, E., 2013, Synergistic Effect of Cinnamon Essential Oil (Cinnamomum burmannii) and Doxorubicin on T47D Cells Correlated with Apoptosis Induction, Indones. J. Cancer Chemoprevent., 4(I), 450-456.

Bansode, R.R., Leung, T., Randolph, P., Williams, L.L. and Ahmedna, M., 2013, Cinnamon Extract Inhibits Angiogenesis in Zebrafish and Human Endothelial Cells by Suppressing VEGFRI,
VEGFR2, and PKC-mediated MAP Kinase, Food Sci. Nutr., I (I), 74-82.

Barceloux, D.G., 2009, Cinnamon (cinnamomum species), Dis. Mon., 55(6), 327-335.

Cabello, C.M., Bair, W.B., Lamore, S.D., Ley, S., Bause, A.S., Azimian, S., et al., 2009, The Cinnamon-Derived Michael Acceptor Cinnamic Aldehyde Impairs Melanoma Cell Proliferation, Invasiveness, and Tumor Growth, Free Radic. Biol. Med., 46(2), 220 $23 \mathrm{I}$.

Chew, E.H., Nagle, A.A., Zhang, Y., Scarmagnani, S., Palaniappan, P., Bradshaw, T.D., et al., 2010, Cinnamaldehydes Inhibit Thioredoxin Reductase and Induce Nrf2: Potential Candidates for Cancer Therapy and Chemoprevention, Free Radic. Biol. Med., 48(I), 98-III.

Chuang, L.Y., Guh, J.Y., Chao, L.K., Lu, Y.C., Hwang, J.Y., Yang, Y.L., et al., 2012, Anti-proliferative Effects of Cinnamaldehyde on Human Hepatoma Cell Lines, Food Chem., 133(4), 1603-1610.

Daker, M., Lin, V.Y., Akowuah, G.A., Yam, M.F. and Ahmad, M., 2013, Inhibitory Effects of Cinnamomum Burmannii Blume Stem Bark Extract and Trans-Cinnamaldehyde on Nasopharyngeal Carcinoma Cells; Synergism With Cisplatin. Exp. Ther. Med., 5(6), I70I1709.

de Oliveira Niero, E.L. and Machado-Santelli, G.M., 2013, Cinnamic Acid Induces Apoptotic Cell Death and Cytoskeleton Disruption in Human Melanoma Cells, J. Exp. Clin. Cancer Res., 32(I), 3I, doi: I0.II86/I756-9966-3231.

Deryugina, E.I. and Quigley, J.P., 2006, Matrix Metalloproteinases and Tumor Metastasis, Cancer Metastasis Rev., 25(I), 934.

Ding, Y., Wu, E.Q., Liang, C., Chen, J., Tran, M.N., Hong, C.H., et al., 20II, Discrimination of Cinnamon Bark and Cinnamon Twig Samples Sourced from Various Countries Using HPLC-based Fingerprint Analysis, Food Chem., I 27(2), 755-760.

Duke, J.A., 1992, Handbook of Phytochemical Constituents of GRAS Herbs and Other Economic Plants, Boca Raton: CRC Press. 
Fang, S.H., Rao, Y.K. and Tzeng, Y.M., 2004, Cytotoxic Effect of Trans-Cinnamaldehyde from Cinnamomum Osmophloeum Leaves on Human Cancer Cell Lines, Int. J. Appl. Sci. Eng., 2(2), I36-I 47.

Finn, O.J., 2012, Immuno-oncology: Understanding the Function and Dysfunction of the Immune System in Cancer, Ann. Oncol., 23(Suppl 8), viii6-9.

Hanahan, D. and Weinberg, R.A., 20II, Hallmarks of Cancer: the Next Generation, Cell, I 44(5), 646-674.

Homma, S., Ishii, Y., Morishima, Y., Yamadori, T., Matsuno, Y., Haraguchi, N., et al., 2009, Nrf2 Enhances Cell Proliferation and Resistance to Anti-Cancer Drugs in Human Lung Cancer, Clin. Cancer Res., I 5( I0), 3423-3432.

Hong, S.H., Kim, J., Kim, J.M., Lee, S.Y., Shin, D.S., Son, K.H., et al., 2007, Apoptosis Induction of 2'-Hydroxycinnamaldehyde as A Proteasome Inhibitor is Associated with ER Stress and Mitochondrial Perturbation in Cancer Cells, Biochem. Pharmacol., 74(4), 557-565.

Huang, Y., Zeng, F., Xu, L., Zhou, J., Liu, X. and Le, H., 20I2, Anti-Cancer Effects of Cinnamic Acid in Lung Adenocarcinoma Cell Line HI299-Derived Stem-Like Cells, Oncology Research Featuring Preclinical and Clinical Cancer Therapeutics, 20(II), 499-507.

Hussain, A., Brahmbhatt, K., Priyani, A., Ahmed, M., Rizvi, T.A. and Sharma, C., 20II, Eugenol Enhances the Chemotherapeutic Potential of Gemcitabine and Induces Anticarcinogenic and Anti-Inflammatory Activity in Human Cervical Cancer Cells, Cancer Biother. Radiopharm., 26(5), 519-527.

Ismail, I.A., Kang, H.S., Lee, H.J., Chang, H., Yun, J., Lee, C.W., et al., 2013, 2Hydroxycinnamaldehyde Inhibits the Epithelial-Mesenchymal Transition in Breast Cancer Cells, Breast Cancer Res. Treat., I37(3), 697-708.

Jaganathan, S.K., Mazumdar, A., Mondhe, D. and Mandal, M., 20I I, Apoptotic Effect of Eugenol in Human Colon Cancer Cell Lines, Cell Biol. Int., 35(6), 607-6I5.

Ka, H., Park, H.J., Jung, H.J., Choi, J.W., Cho, K.S., $\mathrm{Ha}$, J., et al., 2003, Cinnamaldehyde Induces Apoptosis by ROS-Mediated Mitochondrial Permeability Transition in Human
Promyelocytic Leukemia HL-60 Cells, Cancer Lett., 196(2), I43-I52.

Kamaliroosta, L., Gharachorloo, M., Kamaliroosta, Z. and $\mathrm{KH}$, A.Z., 20I2, Extraction of Cinnamon Essential Oil and Identification of Its Chemical Compounds, J. Med. Plants Res., 6(4), 609-614.

Kansanen, E., Kuosmanen, S.M., Leinonen, $H$. and Levonen, A.L., 2013, The Keapl-Nrf2 Pathway: Mechanisms of Activation and Dysregulation in Cancer, Redox Biol., I (I), 4549.

Kim, D.H., Kim, C.H., Kim, M.S., Kim, J.Y., Jung, K.J., Chung, J.H., et al., 2007, Suppression of Agerelated Inflammatory NF-KB Activation by Cinnamaldehyde, Biogerontology, 8(5),545-554.

Kim, S.A., Sung, Y.K., Kwon, B.M., Yoon, J.H., Lee, H., Ahn, S.G., et al., 2010, 2'Hydroxycinnamaldehyde Shows Antitumor Activity Against Oral Cancer in Vitro and in Vivo in A Rat Tumor Model, Anticancer Res., 30(2), 489-494.

Koppikar, S.J., Choudhari, A.S., Suryavanshi, S.A., Kumari, S., Chattopadhyay, S. and KaulGhanekar, R., 2010, Aqueous Cinnamon Extract (ACE-c) from the Bark of Cinnamomum Cassia Causes Apoptosis in Human Cervical Cancer Cell Line (SiHa) through Loss of Mitochondrial Membrane Potential, BMC cancer, $10(1), 210$, doi: I0.1 I86/I47I-2407-10-2I0.

Kwon, H.K., Jeon, W.K., Hwang, J.S., Lee, C.G., So, J.S., Park, J.A., et al., 2009, Cinnamon Extract Suppresses Tumor Progression by Modulating Angiogenesis and the Effector Function of CD8+ T cells. Cancer Lett., 278(2), I74- 182.

Kwon, H.K., Hwang, J.S., So, J.S., Lee, C.G., Sahoo, A., Ryu, J.H., et al., 2010, Cinnamon Extract Induces Tumor Cell Death through Inhibition of NFKB and API, BMC cancer, I0(I), 392, doi: I0.I I86/I47I-2407-10-392.

Larasati, Y.A., Putri, D.D.P., Utomo, R.Y., Hermawan, A. and Meiyanto, E., 2014, Combination of Cisplatin and Cinnamon Essential Oil Inhibits HeLa Cells Proliferation through Cell Cycle Arrest, J. Appl. Pharm. Sci., 4(I2), I4-19.

Lee, S.Y., Kim, H.S., Kim, J.O., Hwang, S.W. and Hwang, S.Y., 2006, Effect of Ethanol Extracts of Cinnamon on The Proliferation and COX- 
2 Pathway in HT-29 Human Colon Cancer Cell Line, J. Korean Soc. Food. Sci. Nutr., 35(9), III5-II 20.

Lee, C.W., Lee, S.H., Lee, J.W., Ban, J.O., Lee, S.Y., Yoo, H.S., et al., 2007, 2Hydroxycinnamaldehyde Inhibits SW620 Colon Cancer Cell Growth through AP-I Inactivation, J. Pharmacol. Sci., 104(I), 19-28.

Lee, M.A., Park, H.J., Chung, H.J., Kim, W.K. and Lee, S.K., 20I3, Antitumor Activity of 2Hydroxycinnamaldehyde for Human Colon Cancer Cells Through Suppression of BCatenin Signalling, J. Nat. Prod., 76(7), I2781284.

Ma, Y.Y., Huo, H.R., Li, C.H., Zhao, B.S., Li, L.F., Sui, F., et al., 2008, Effects of Cinnamaldehyde on PGE2 Release and TRPV4 Expression in Mouse Cerebral Microvascular Endothelial Cells Induced by Interleukin-I $\beta$, Biol. Pharm. Bull., 3 I (3), 426-430.

Manikandan, P., Vinothini, G., Priyadarsini, R.V., Prathiba, D. and Nagini, S., 20II, Eugenol Inhibits Cell Proliferation via NF-kB Suppression in a Rat Model of Gastric Carcinogenesis Induced by MNNG, Invest. New Drugs., 29(I), II0-I 17.

Mao, J.T., Roth, M.D., Fishbein, M.C., Aberle, D.R., Zhang, Z.F., Rao, J.Y., et al., 20II, Lung Cancer Chemoprevention with Celecoxib in Former Smokers, Cancer Prev. Res., 4(7), 984993.

Nagle, A.A., Gan, F.F., Jones, G., So, C.L., Wells, G. and Chew, E.H., 20I2, Induction of Tumor Cell Death through Targeting Tubulin and Evoking Dysregulation of Cell Cycle Regulatory Proteins by Multifunctional Cinnamaldehydes, PloS one, 7(I I), e50I 25.

Patra, K., Bose, S., Sarkar, S., Rakshit, J., Jana, S., Mukherjee, A., et al., 2012, Amelioration of Cyclophosphamide Induced Myelosuppression and Oxidative Stress by Cinnamic Acid, Chem.-Biol. Interact., 195(3), 23I-239.

Ranasinghe, P., Jayawardana, R., Galappaththy, P., Constantine, G.R., de Vas Gunawardana, N. and Katulanda, P., 2012, Efficacy and Safety of 'True'cinnamon (Cinnamomum zeylanicum) as a Pharmaceutical Agent in Diabetes: a
Systematic Review and Meta-analysis, Diabet. Med., 29(I2), I480-I492.

Ranasinghe, P., Pigera, S., Premakumara, G.S., Galappaththy, P., Constantine, G.R. and Katulanda, P., 2013, Medicinal Properties of 'True'cinnamon (Cinnamomum zeylanicum): A Systematic Review, BMC Complement. Altern. Med., 13(I), 275, doi: 10.1 186/14726882-13-275.

Schoene, N.W., Kelly, M.A., Polansky, M.M. and Anderson, R.A., 2005, Water-soluble Polymeric Polyphenols from Cinnamon Inhibit Proliferation and Alter Cell Cycle Distribution Patterns of Hematologic Tumor Cell Lines, Cancer Lett., 230(I), I34-I40.

Shibata, T., Kokubu, A., Gotoh, M., Ojima, H., Ohta, T., Yamamoto, M., et al., 2008, Genetic Alteration of Keapl Confers Constitutive Nrf2 Activation and Resistance to Chemotherapy in Gallbladder Cancer, Gastroenterology, 135(4), I358-1368.

Singh, R., Koppikar, S.J., Paul, P., Gilda, S., Paradkar, A.R. and Kaul-Ghanekar, R., 2009, Comparative Analysis of Cytotoxic Effect of Aqueous Cinnamon Extract from Cinnamomum zeylanicum Bark With Commercial Cinnamaldehyde on Various Cell Lines, Pharm. Biol., 47(I2), I I74-I I 79.

Sosa, V., Moliné, T., Somoza, R., Paciucci, R., Kondoh, H. and LLeonart, M.E., 20I3, Oxidative Stress and Cancer: An Overview, Ageing Res. Rev,. I 2(I), 376-390.

Tsai, C.M., Sun, F.M., Chen, Y.L., Hsu, C.L., Yen, G.C. and Weng, C.J., 20I3, Molecular Mechanism Depressing PMA-induced Invasive Behaviors in Human Lung Adenocarcinoma Cells by Cis-And Trans-Cinnamic Acid, Eur. J. Pharm. Sci., 48(3), 494-50I.

Wondrak, G.T., 2009, Redox-directed Cancer Therapeutics: Molecular Mechanisms and Opportunities, Antioxid. Redox Signal., I I (I2), 3013-3069.

Wondrak, G.T., Villeneuve, N.F., Lamore, S.D., Bause, A.S., Jiang, T. and Zhang, D.D., 2010, The Cinnamon-Derived Dietary Factor Cinnamic Aldehyde Activates the Nrf2Dependent Antioxidant Response in Human Epithelial Colon Cells, Molecules, I5(5), 33383355. 
Yamakawa, D., Kidoya, H., Sakimoto, S., Jia, W. and Takakura, N., 20II, 2Methoxycinnamaldehyde Inhibits Tumor Angiogenesis by Suppressing Tie2 Activation, Biochem. Biophys. Res. Commun., 4 I 5(I), I74180.

Yen, G.C., Chen, Y.L., Sun, F.M., Chiang, Y.L., Lu, S.H. and Weng, C.J., 20II, A Comparative Study on The Effectiveness of Cis-and Transform of Cinnamic Acid Treatments for Inhibiting Invasive Activity of Human Lung Adenocarcinoma Cells, Eur. J. Pharm. Sci., 44(3), 28I-287.

Yu, T., Lee, S., Yang, W.S., Jang, H.J., Lee, Y.J., Kim, T.W., et al., 2012, The Ability of an Ethanol
Extract of Cinnamomum cassia to Inhibit Src and Spleen Tyrosine Kinase Activity Contributes to Its Anti-inflammatory Action, J. Ethnopharmacol., I39(2), 566-573.

Zhang, J.H., Liu, L.Q., He, Y.L., Kong, W.J. and Huang, S.A., 2010, Cytotoxic Effect of TransCinnamaldehyde on Human Leukemia K562 Cells, Acta Pharmacol. Sin., 3 I (7), 86 I-866.

Zhang, C., Li, C., Sui, F., Lu, Y., Li, L., Guo, S., et al., 2012, Cinnamaldehyde Decreases Interleukin-Ibeta Induced PGE2 Production by Down-regulation of mPGES-I and COX-2 Expression in Mouse Macrophage RAW264. 7 cells, Zhongguo Zhong Yao Za Zhi., 37(9), I 274- 1278. 